\title{
Dermoscopic appearance of a rare localization of merckel carcinoma
}

\section{Sara Elloudi, Fatima Zahra Mernissi}

Department of Dermatology, University Hospital center Hassan II, Faculty of Medecine, University Sidi Mohammed Ben Abdellah, Fez, Morocco

Corresponding author: Sara Elloudi, MD, PhD, E-mail: dr.elloudi@gmail.com

Sir,

Merckel carcinoma is a very rare malignant tumor, occurring in the elderly, frequently localized at the cervico-cephalic extremity. We report an observation of a middle-aged man with merckel carcinoma in the right buttock, and we describe his dermoscopic appearance.

A 53-year-old man had presented a tumor in the right gluteal region for 7 months. Dermatologic examination showed an ulcerative budding tumor $10 \mathrm{~cm}$ in diameter taking the right gluteal region bleeding on contact. Dermoscopy objectified milky red areas, chrysalids, white circles making white network or an inverted network like with red globules (Fig. 1). A skin biopsy was in favor of Merkel cell carcinoma (MCC).

MCC is a malignant neuroendocrine skin tumor at the expense of Merkel cells affecting humans

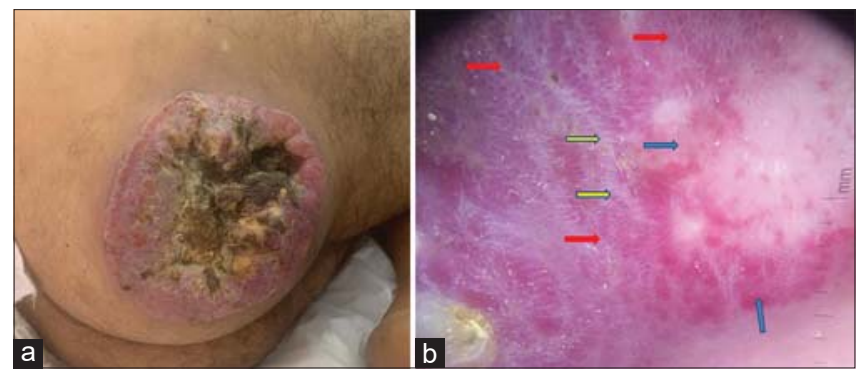

Figure 1: (a) Ulcerated tumor of the right buttock, (b) Dermoscopic appearance of the tumor Legends: Yellow arrows: chrysalides; Red arrows: white circles making white network or inverted network like with red globules; Blue arrows: milky red area. over the age of 70 . The most common location is the cervico-cephalic extremity. That of the gluteal region is very rare. Merckel carcinoma dermoscopy is not specific [1]. Biopsy with immunohistochemistry confirms the diagnosis. For localized MCC, a wide excision with a $2-3 \mathrm{~cm}$ margin is the treatment of choice. In the face of risk factors, adjuvant radiotherapy is suggested [2]. This was the case with our patient.

Dermoscopy of Merckel carcinoma is rarely reported in the literature, we report a new dermoscopic pattern of this tumor with such a rare localization.

\section{CONSENT}

The examination of the patient was conducted according to the principles of the Declaration of Helsinki.

The authors certify that they have obtained all appropriate patient consent forms, in which the patients gave their consent for images and other clinical information to be included in the journal. The patients understand that their names and initials will not be published and due effort will be made to conceal their identity, but that anonymity cannot be guaranteed.

\section{Ethics Statement}

Ethical approval was obtained from the ethics committees at the faculty of Medecine, University Sidi Mohammed Ben Abdellah in Fez, Morocco. the patient was informed of the conditions related to the study and gave their written informed consent for the study and for publication.

\footnotetext{
How to cite this article: Elloudi S, Mernissi FZ. Dermoscopic appearance of a rare localization of merckel carcinoma. Our Dermatol Online. 2021;12(e):e68.

Submission: 14.04.2021; Acceptance: 15.09.2021

DOI: 10.7241 /ourd.2021e.68
} 
www.odermatol.com

\section{REFERENCES}

1. Jalilian C, Chamberlain AJ, Haskett M, Rosendahl C, Goh M, Beck $\mathrm{H}$ et al. Clinical and dermoscopic characteristics of Merkel cell carcinoma. Br J Dermatol. 2013;169:294-7.

2. Tiffany LT, Kathleen C, Sue SY, Siegrid SY. Merkel cell carcinoma: An update and review. Part II. JAAD. 2018;78:445-54.
Copyright by Sara Elloudi, et al. This is an open-access article distributed under the terms of the Creative Commons Attribution

License, which permits unrestricted use, distribution, and

reproduction in any medium, provided the original author and source

are credited.

Source of Support: Nil, Conflict of Interest: None declared. 